\title{
Arrivals and Departures: Understanding Cultural Memory in The Terminal
}

\author{
Kanika Sharma \\ Shyama Prasad Mukherji College, University of Delhi, New Delhi. \\ Received May 27, 2017; Revised July 18, 2017; Accepted July 25, 2017; Published August o8, 2017.
}

\begin{abstract}
This paper attempts to understand the space of the airport, and locate the interaction of an individual that inhabits this space, particularly when this space of transit becomes more than a static portal. The space of the airport is architecturally informed with a universal language and this language dictates the movements of the individual. The dynamics of this spatial language is intentionally designed to be trans-historic, devoid of a past, and solely for the consumption of a solitary traveller. However this definition of the airport gets redefined when the movement of the individual is stalled and turns into an undefined wait, such a representation is presented through Spielberg's The Terminal. This paper will explore these issues about a traveller's filiations and affiliations with the space of airport, the first part of the study will scale out the argument by understanding the category of non-places, and in the second part, a discussion of the above mentioned scenario will be construed through the example of the same in 2004, Steven Spielberg's movie The Terminal.
\end{abstract}

Keywords: Marc Augé, Non-place, cultural memory, space, The Terminal.

Marc Augé in his exemplary study Non-places: Introduction to an anthropology of Supermodernity, brings together the classic understandings of space, in his third chapter of the book titled "Places and Non-places", he defines non-place, by what it is not, he writes,

"If a place can be defined as relational, historical and concerned with identity, then a space which cannot be defined as relational, or historical, or concerned with identity will be a nonplace." (Augé, 1992, pp. 76-77)

The hypothesis that he lays in this chapter is based on the reading of contrasts in literary and visual culture of modernism and postmodernism or supermodernism/over-modernity. While the former has the ability to capture the past with the present and the ephemeral with the eternal, the latter presents a "dense network" of fleeting, abstract and ephemeral "solitary individuality" that creates spaces of habit, luxury and transits devoid of any relational or cultural marker. Functioning much like Jameson's late capitalist society, supermodernity is a world,

...where people are born in the clinic and die in hospital, where transit points and temporary abodes are proliferating under luxurious or inhuman conditions (hotel chains and squats, holiday clubs and refugee camps, shantytowns threatened with demolition or doomed to festering longevity); where a dense network of means of transport which are also inhabited spaces is developing; where the habitué of supermarkets, slot machines and credit cards

(C) AesthetixMS 2016. This Open Access article is published under a Creative Commons Attribution Non-Commercial 4.0 International License (http://creativecommons.org/licenses/by-nc/4.0/), which permits non-commercial re-use, distribution, and reproduction in any medium, provided the original work is properly cited. For citation use the DOI. For commercial re-use, please contact editor@rupkatha.com. 
communicates wordlessly, through gestures, with an abstract, unmediated commerce... (Augé, 1992, p. 78)

He attempts to chart out the aspect of time, space and identity in the times of supermodernity and ethnographically presents the 'everyday' with the interaction of individual with its spaces. He propounds that there are three notable excesses, overabundance of time, overabundance of space, and changed definitions of individuality, and this all has led to supermodernity and creation of non-places.

Furthermore he underlines that just like place, non-place is also not a pure category and there is a constant reformulation of place and placelessness within it. Augé asserts that place and non-pace are based on Michel de Certeau's category of place and space, where former has a symbolic ordering and geographical rigidity and latter is an ambiguous actualization of a place.

the real non-places of supermodernity - the ones we inhabit when we are driving down the motorway, wandering through the supermarket or sitting in an airport lounge waiting for the next flight to London or Marseille - have the peculiarity that they are defined partly by the words and texts they offer us: their 'instructions for use', which may be prescriptive ('Take right-hand lane'), prohibitive ('No smoking') or informative ('You are now entering the Beaujolais region'). (Augé, 1992, p. 101)

These spaces encourage the individual to have a transaction with the space through the codified language that it provides; the society will never participate as collective as there is no space for such interaction. For instance, separate screen monitors in front of each seat in an airplane, or benches, if any in the mall, are facing the advertisements or stores rather than an arena for dialogue. Augé further insists on the importance to look at the non-symbolic language of nonplace in a positive way rather than earlier theories of reading it as a void or a lack, he asserts, "the term 'space' is more abstract in itself than the term 'place', whose usage at least refers to an event (which has taken place), a myth (said to have taken place) or a history (high places)" (Augé, 1992, p. 82). These non-places devoid of the essential categories that should be a part of an anthropological space are all we are left with in a supermodern reality. These places have specific ends in their construction and are geographically laid out to create a similar-looking space. According to Augé, these spaces create an aspect of 'solitary individuality', an individual self that is concerned with the interaction with the space of non-place than the people within it. So not only a non-place is devoid of historical narratives from the past, it has no collective participation, and the individual self meets with only an image of itself and that too for a transitory period.

Despite Augé's constant insistence throughout the book to create a positive research overlay for non-space, one can sense some pessimism in his descriptions, as Ian Buchanan and Gregg Lambert in their introduction to the book Deleuze and space highlight,

"Augé takes this [de Certeau's reversed theory] a step further and develops an idea of the non-place, that is, a place which no longer confers the affect of place, and in the process crushes the creative and indeed anarchic spirit of de Certeau's notion of space"' (Buchanan \& Lambert, 2005, p. 5)

The loss of the creative and anarchic spirit of Certeau's space cannot be restored in Augé nonplace as it is a product of supermodernity, which does not allow that evolution of a place to become space. Despite this, one can read the determination in Augé's book, to pay critical importance to theorize the non-place, and to explain the transitory nexus of solitary individual he 
explains it through the contractual relationship a traveller has with the non-place. (Matienzo, 2004)

Augé explains this exchange with the non-place through the example of a traveller's gaze, which is, "a simultaneous distancing from the spectator and the spectacle" (Augé, 1992, p. 91). He further explains that spectator in essence becomes his own spectacle- one can read such a deflection in tourism pamphlets, which offer scenic images of traveller enjoying the spectacle, "his own image in a word, his anticipated image, which speaks only about him but carries another name." (Augé, 1992, p. 91). He contends that it is only in these solitary travellers, 'who ought to contemplate', and not professional ones, that one sees 'prophetic invocations' of space,

in which neither identity, nor relations, nor history really make any sense; spaces in which solitude is experienced as an overburdening or emptying of individuality, in which only the movement of fleeting images enables the observer to hypothesize the existence of a past and glimpse a future. (Augé, 1992, p. 92)

Before we discuss the space of the airport terminal in detail along with the elements of subversion that Speilberg's movie The Terminal poses to Augé theory of non-place, it is helpful to look at some internal ambiguities in the definition of non-place as presented by Augé. Peter Osborne in his essay, "Non-place and Spaces of Art", states

...Augés presentation of the concept of non-place is both theoretically ambiguous and critically ambivalent. Theoretically, it equivocates between an abstract and a dialectical conception of negation. Critically, it oscillates between a backward-looking romanticisation of the anthropological conception of place and a forward-looking positive 'ethnology of solitude'. This is the result of the restrictions of the anthropological perspective. (Osborne, 2001, p. 188)

Erdem Üngür, in his paper 'Contradiction and Ambiguity in Non-Place: Non-Place as a Transitional Spatial Concept', further explains that besides such an ambiguity, the subject and its transaction with the examples of non-space given by Augé is not described clearly. One of the main contentions of scholars, like Üngür, Chiara D. Libraii and Tim Gregory, is that the definition of non-place will change for different individuals on the basis of their activity in the non-place and also with different generations the interaction will vary. Üngür quotes from Gregory's unpublished thesis, "No Alarms and No Surprises: The Rise of the Domestic Non-Place",

For Augé it is the very fact that the non-place is uninhabitable that gives it its defining characteristics. This position ignores the workers within the malls; the security guards, cleaners and retail staff, who have a very different experience of the mall from consumers (likewise the toll collector on a freeway and the receptionist at a motel)... Non-place did not die but rather that it is making its invisible presence felt in other spaces: spaces that do not hold true to Augé's original qualification for transit (Üngür, 2012, p. 8)

This contention is something that Steven Speilberg extensively explores in his 2004 movie The Terminal. Not only does he present an array of individuals coming from different registers and therefore formulating different relations with the space of the airport terminal, but also presents a traveller who gets mired in the nexus of the new codes of this unintelligible non-place and how he successfully tutors himself; not just linguistically by learning a new language but by also learning the language of an airport, by understanding the codes and symbols of an airport terminal and 
therefore creating a new identity for himself and becoming a locus of a collective that participates inside the space of the airport terminal.

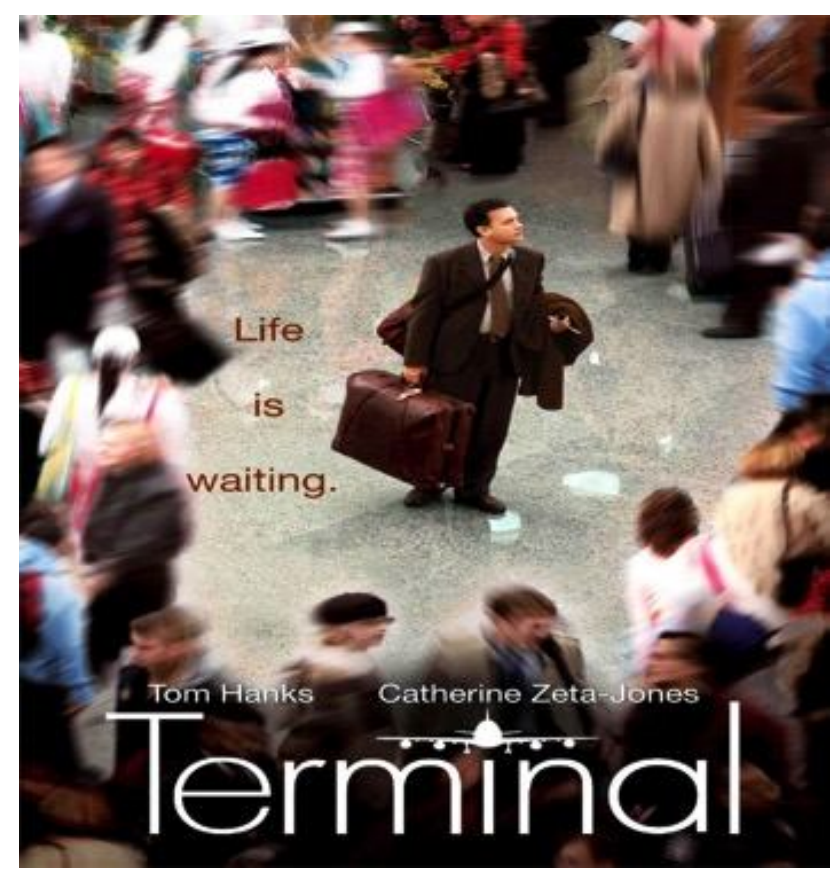

Fig. 1: Poster of the movie The Terminal, 2004

Airports hold a diverse nexus of mobility and consumerism, architecturally airports are deigned to give a sense of vastness that is unending, one needs to follow a grid to get to places which might not make any sense if one does not follow the signs around the space of an airport. The terminal space is infused with cybernetic network of surveillance where both the waiting and mobility are directed.

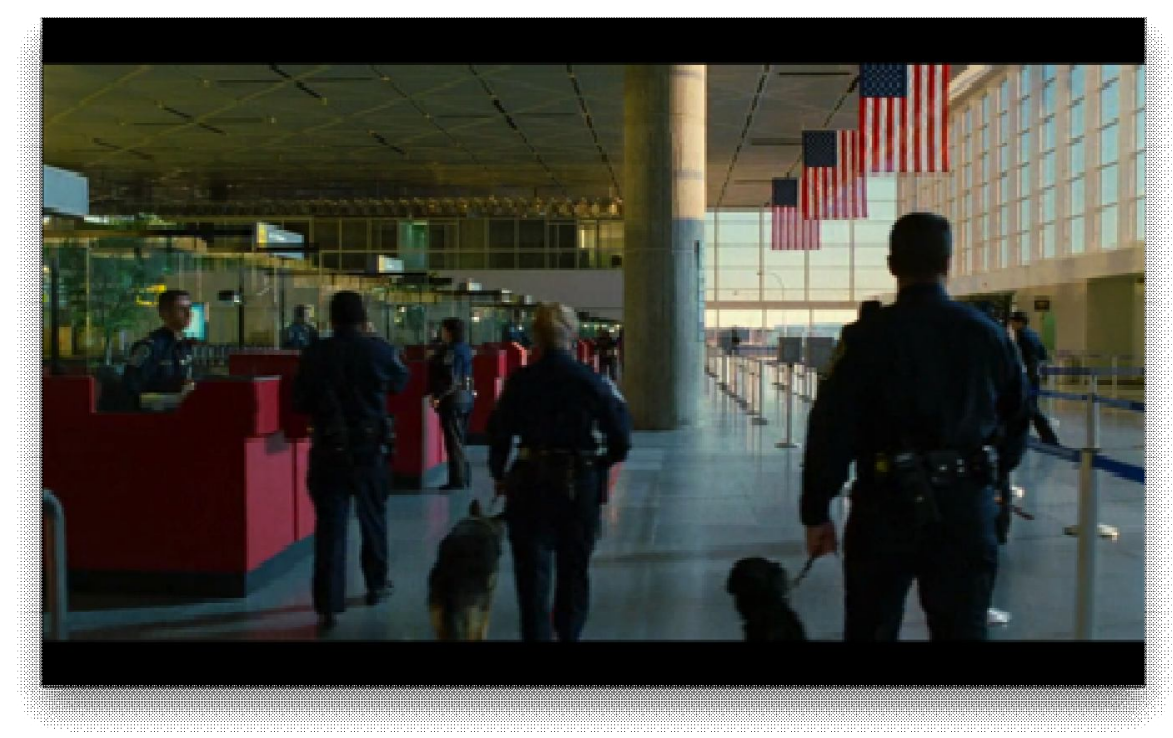

Fig. 2: Long passages filled with security barricading movement and spaces 
Though Spielberg based his story on Nasseri, he changed a lot of important details; for instance, the amount of time the character in the movie spends at the airport is far less than Nasseri's ordeal of 28 years. Along with that Spielberg did not reflect on the neurological imbalance Nasseri was suffering from, due to his containment in the liminal space of an airport. The aspect of the wait that Spielberg explores in the movie seems like a romanticized version of the haunting reality of it as lived by Nasseri.

Throughout the movie, Spielberg has tried to give a sense of vastness to the JFK airport through his long shots and the constant confusion of Victor Navroski to find his way around the airport. The movie opens by highlighting the mapped network of surveillance and security, and following that a very efficient traffic flow of passengers, as the vast group of travellers authenticate their identity and get screened before an officer.

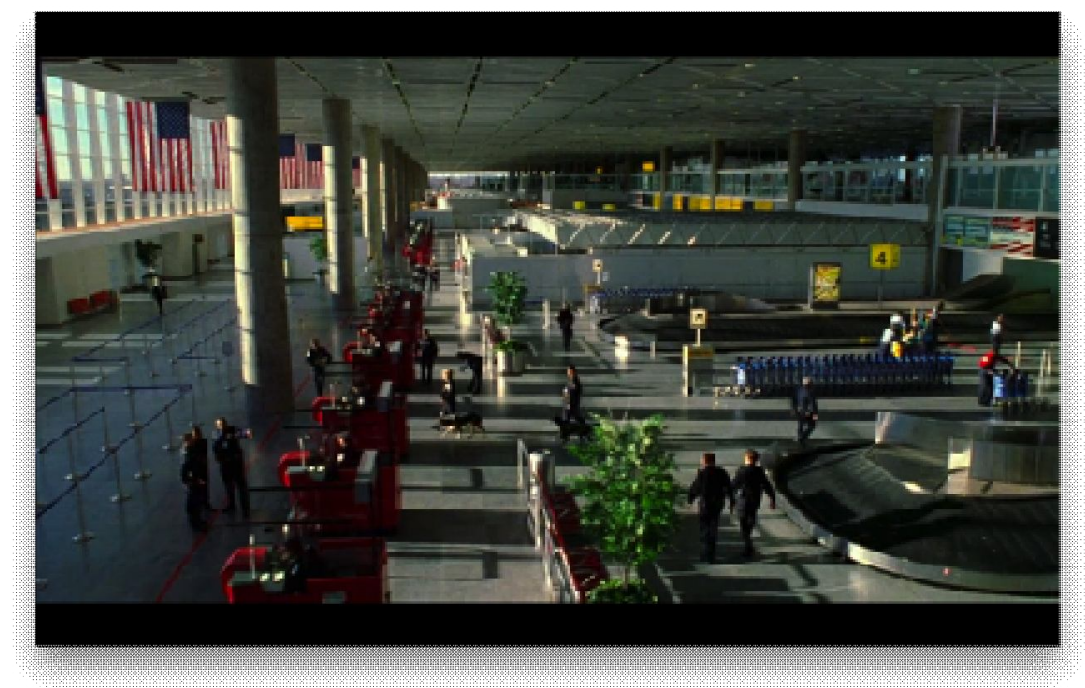

Fig. 3: Another long shot establishing vastness

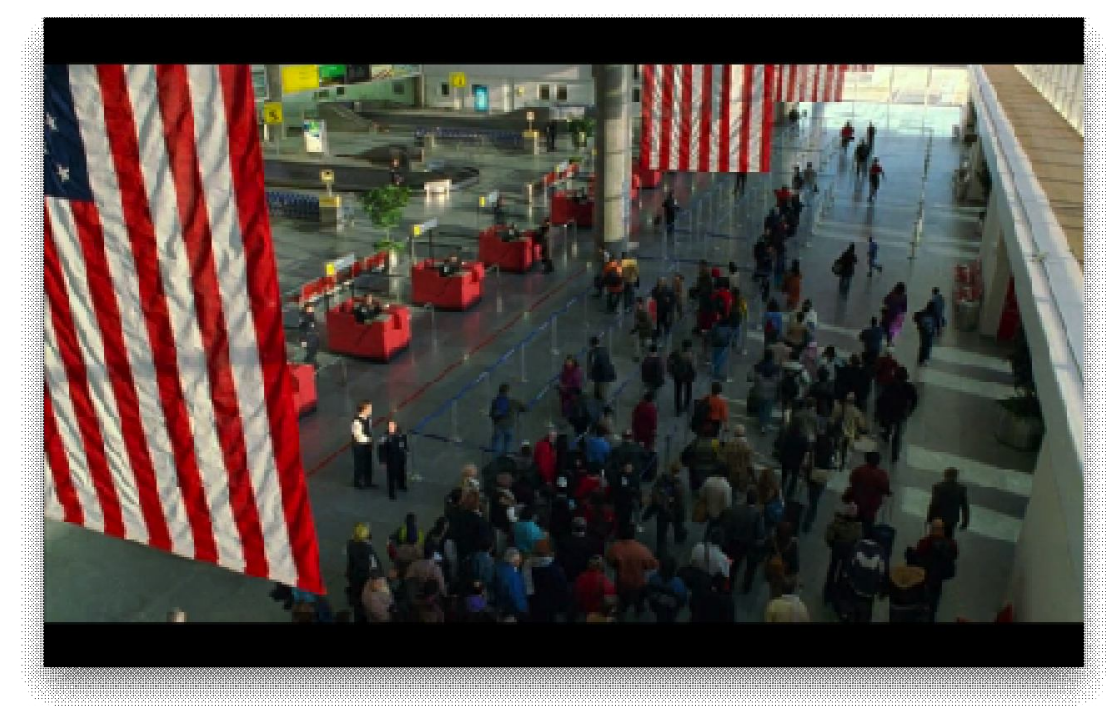

Fig. 4: Collective is distinctly divided and lined up 
In an interesting paper on airport signage and the social semiotics of its interaction with the travellers, titled "The Arrow-Directional Semiotics: Wayfinding in Transit", Gillian Fuller explains,

Signage virtualises the social relations of individuals into the anonymity of crowd control, reconfiguring territories of geophysical/architectural/ cultural space into territories of recognition and action that speak to a productive power of language that exceeds representation...Within airports, managing spatial flow is crucial. An airport processes traffic; it is a machine for capturing and controlling flows at the most literal and abstract levels. The movements of people, machines, and cargo are kept steady and separate. Moving in relay from point to point, each must connect at certain points and then continue along fixed paths and at fixed speeds. All movement is controlled, from the planes on the apron to the corralling of passengers in retail areas. (Fuller, 2002, pp. 231233)

The movie showcases the US airport after the 9/11 attack and the surveillance is heightened for entering into the United States of America. The immigration officers welcomes travellers of different ethnicities and inquire about their visit, and while this identity-check is in process, the higher officers "are fishing" for possible threats to the smooth traffic of the airport on their surveillance monitors.

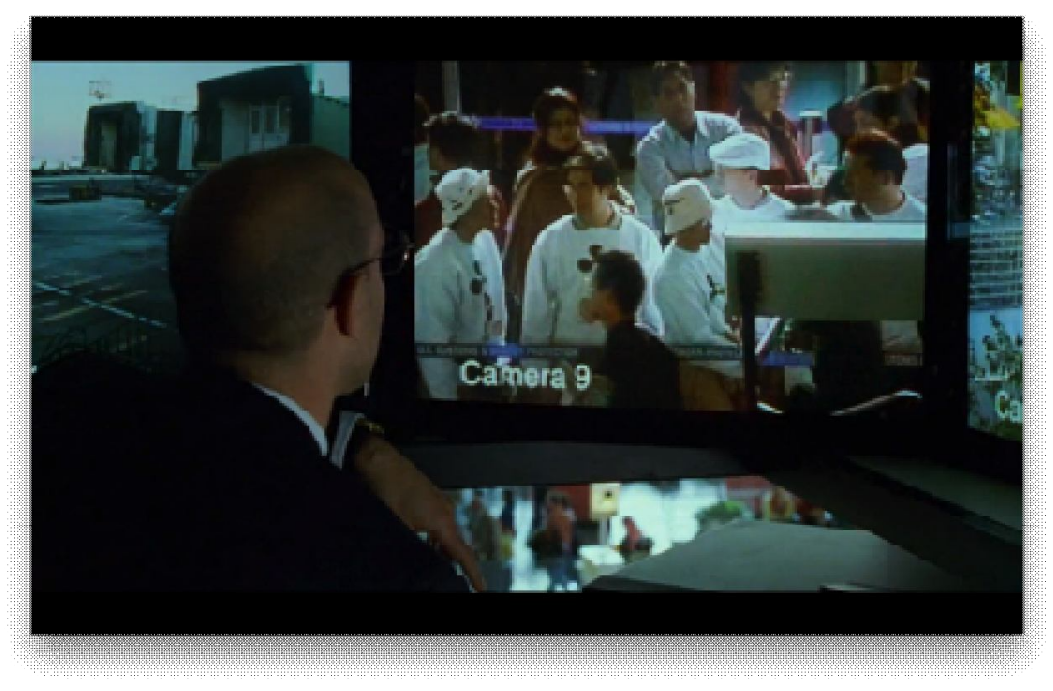

Fig. 5: Layers of surveillance dictates the language of the airport

Amidst this confusion of catching the threatening elements, i.e. a group of Chinese people posing as tourists; we meet Victor Navroski, who is unable to understand the sudden disruption. A sudden rejection on the machine of Navroski barcoded passport sends him into further chaos as he is unable to comprehend the language and follows everything on the basis of signs. Fuller explains,

The rest of the airport turns in on itself in standardised fonts and pictograms and refers no further than the runway and road. The airport is endophoric, endlessly pointing within itself. The place where you are, say Singapore or Sydney, is an attraction/distraction from the space you are in; you can engage with place if you have 
the time or money, but the space needs you to move. (Fuller, 2002, p. 232)

Peter Adey, discusses this containment of a traveller in a airport through his study of surveillance machines that are used in an airport, everything from (Automated archway detection metres) ADM's, automated doors to cameras and integrated software processing, controlling the mobility according to its institutional authority. Just like Victor Navroski, this containment and participation with the signage is never conscious. More than aiding the traveller, signs command and insist on constant movement throughout the airport. ${ }^{\mathrm{iii}}$ Adey further explains,

A passenger becomes reduced to the term 'pax' (the reductionist label that airports give to passengers) and enters airport processing to be modelled by software such as 'Airport Machine'. The automated systems of surveillance take over; passengers are scanned like a bar code and are silently organised and processed through the airport. These questions clearly need attention. (Adey, 2003, p. 1377)

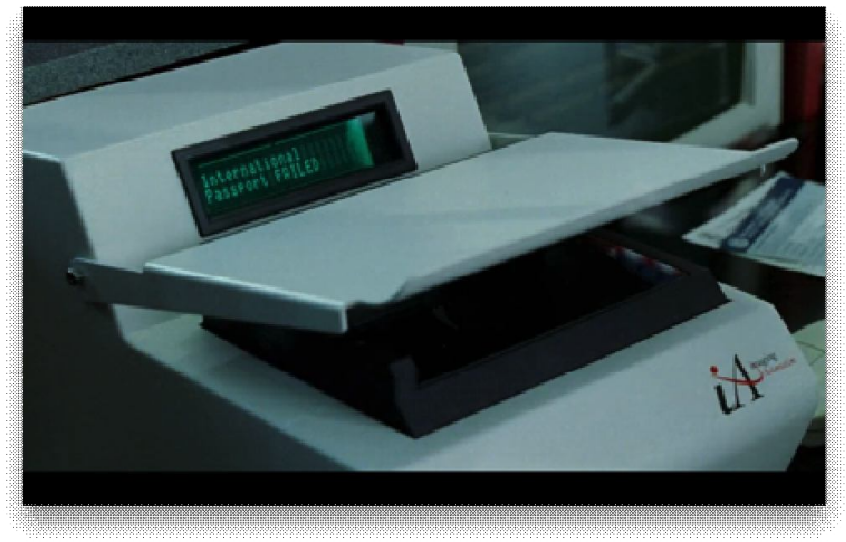

Fig. 6: Individual self is reduced to numbers and barcodes for better assimilation and reference

Victor Navroski is then escorted to the immigration office for further inspection and is constantly given directions of command by the immigration and customs officers,

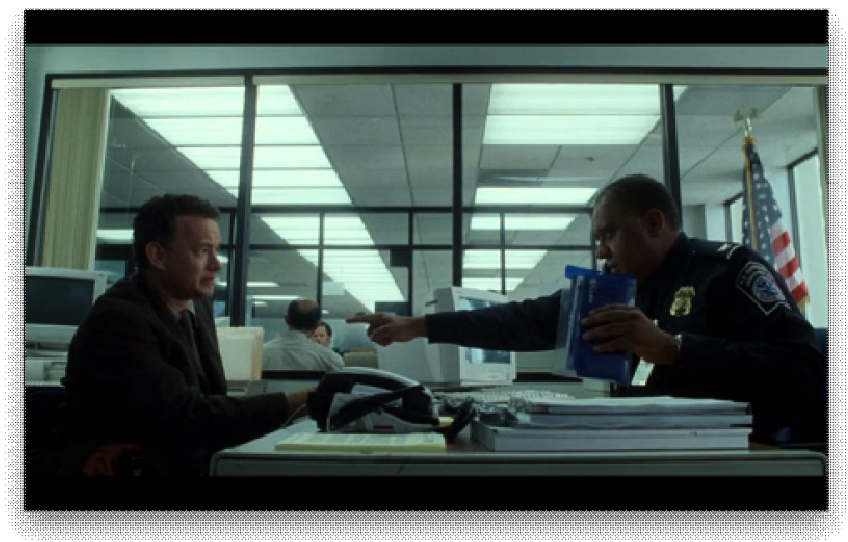

Fig. 7: Signage is the only language that is comprehensible to Navroski 


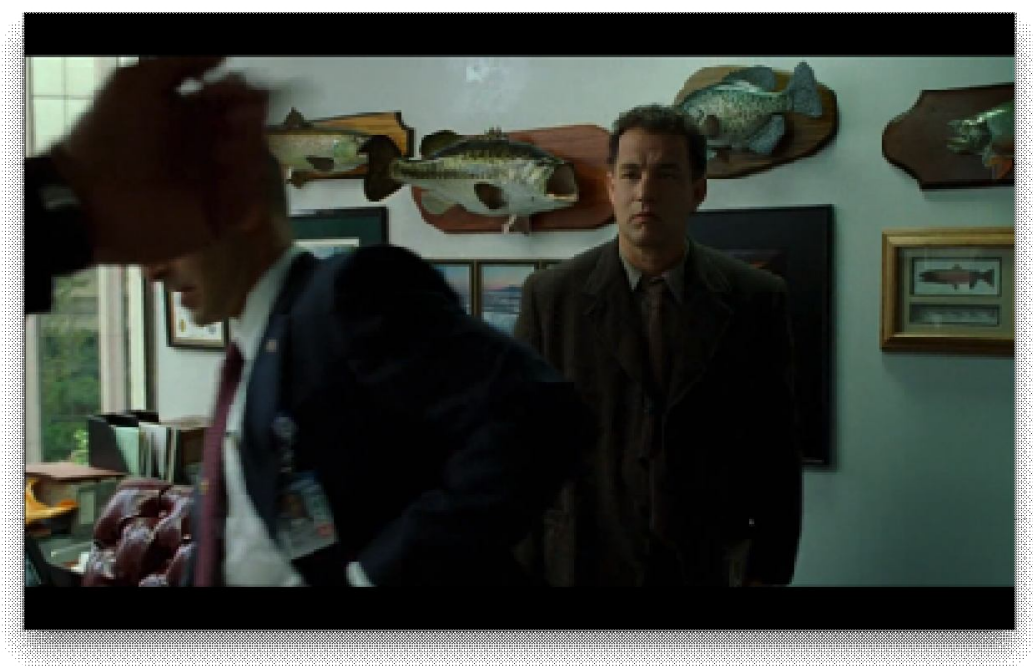

Fig. 8: Constant direction of movement is dictated

Navroski's passport and return ticket are then confiscated without any explanation and the customs officer falsely reassures him that "it is a standard procedure." Speilberg wonderfully captures the confusion of an Eastern European who does not know English, in decoding their complicated and unintelligible official jargon. With each question, he communicates by answering in tourist's stock phrases,

Immigration Officer: What exactly are you doing in the USA?

Viktor Navroski: Yellow taxicab. Take me to Ramada Inn, 161 Lexington.

Immigration Officer: You're staying at the Ramada Inn?

Viktor Navroski: Keep the change.

This incomprehension of the English language triggers a humorous exchange in this sequence, which is actually quite distressing. Despite their graphical illustration of the civil coup that has happened in Karkozhia, they are unable to explain to Victor the reason for him being "unacceptable" at this point in time. It is only later when he hears his country's anthem being played on a television screen in a busy terminal, does he follow the visuals telling him about the military coup in Karkozhia. As he is stateless during the time of the war he cannot return to his own country and as he is also without an identity, he cannot enter United States of America. He, as the officer explains, has fallen into a "small crack in the system" and is supposed to wait in the airport, until the authorities sort his status.

The initial movement of Victor in the international terminal is of confusion and distress as not only he is unable to understand the language but also his stasis in a place infused with mobility is present in the mis en scène. He finds it difficult to communicate even the basic things for which he wants their help and sadly and aimlessly sit amidst a constantly moving crowd. 


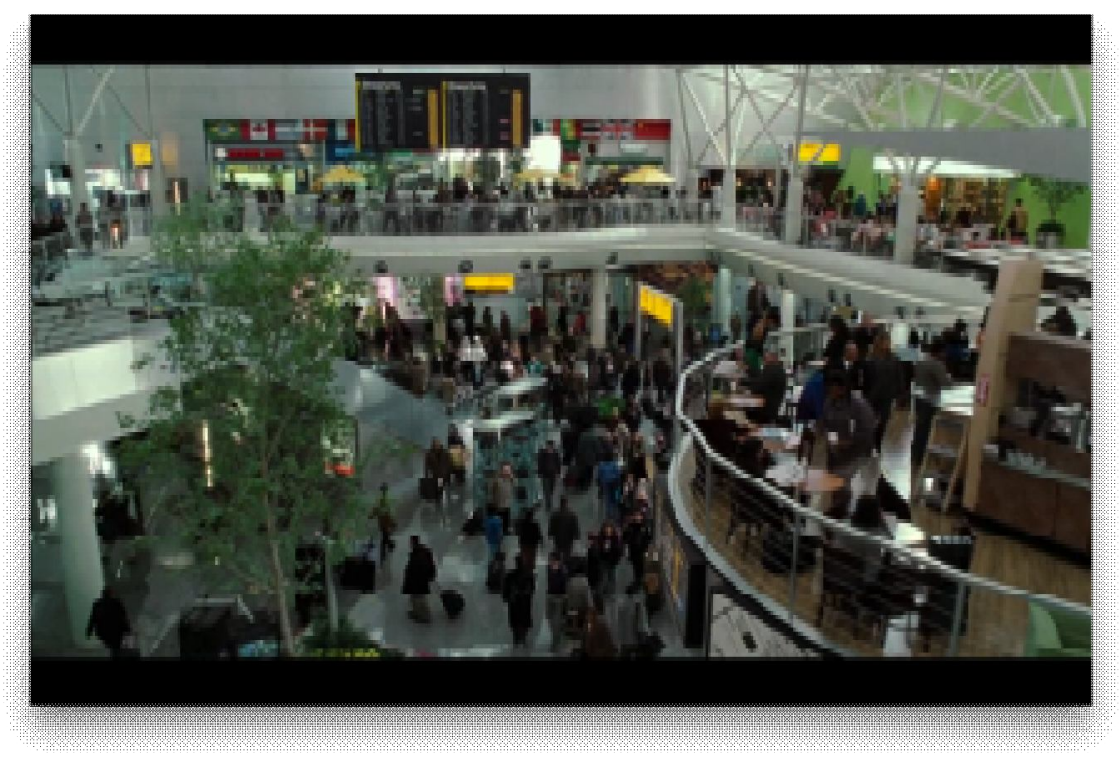

Fig. 9: Another long shot that pans out to highlight the vastness

The international transit lounge where Victor was asked to wait was filled luxuries and comforts but he can only interact with the space through money, and soon we find him having figured out a way to earn money, by returning trollies. While that feeds Victor for some time, Tom Dixon (Stanley Tucci), the chief of Immigration department and also the 'villain' of the movie, soon stops him, while trying his best to get rid of Victor and make him cross the doors of the airport so that he becomes someone else's problem. Despite being in a space filled with people, Navroski is unable to communicate with anyone, his movements become clumsy and directionless.

Victor stays at the transit lounge for nine months, and throughout the narrative the camera constantly shifts from a surveillance camera feed of all his movement in the space of the airport to the actual camera that captures his subversions and methods around the space, against a light comical background score. The narrative shows his development from a confused and constantly directed individual to an informed individual who not only acquires English as a language but also gets well versed in the workings of the airport, all of which allows him to subvert the codes of the space and reconstruct his own space within it. Victor goes on to befriend and become part of a group of workers at the airport; interestingly all three of them are 'outsiders' either racially or ethnically. Much like Victor, their transactions with the airport are also not defined by the conventional sense of it being a temporary transit point, and they have habituated various spaces of the airport as their own, for instance the cargo area where they play poker, and the under constructed area of the airport primarily Gate 67 where Navroski 'lives'. The lack of language does not create impediments for this group, rather we see them bonding, helping each other and acknowledging each other's eccentricities. He helps Enrique, who is a food supplies porter at the airport, to propose to Dolores, and eventually they get married, which is celebrated within the precincts of the airport. 


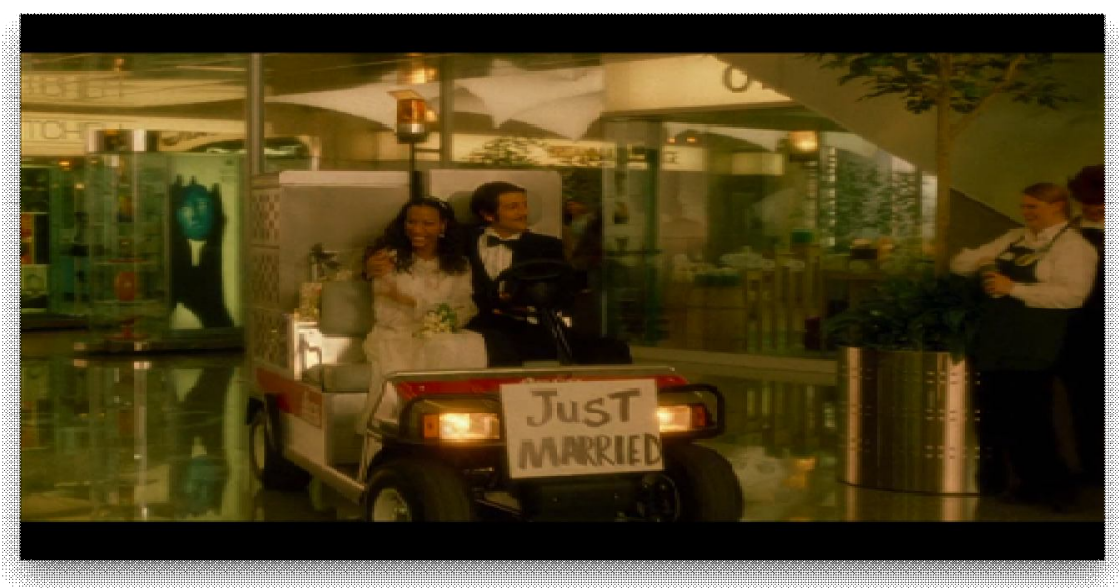

Fig. 10: Wedding takes place inside the airport

The space of the airport from individuals walking with their bags for their flights or waiting and shopping at the terminal lounge suddenly shows a collective formulated within the airport. This collective not only recognizes Navroski as an individual but also celebrates him as a hero. Navroski shows another instance of outmaneuvering the systematic jargon by acquiring the knowledge of the forms and permissions and helping another foreign traveller who got mired in by the 'system' for not having right forms for carrying medicines for his dying father. By telling Dixon that the man is carrying medicines for his goat rather than his father, he saves the medicines, a plot that Dixon realizes but is unable punish him. Spielberg captures the transition of Navroski's unacceptable status at the airport to a hero, after this incident he is lovingly referred to as the goat man, and everyone all around the airport posts his photocopied handprints.

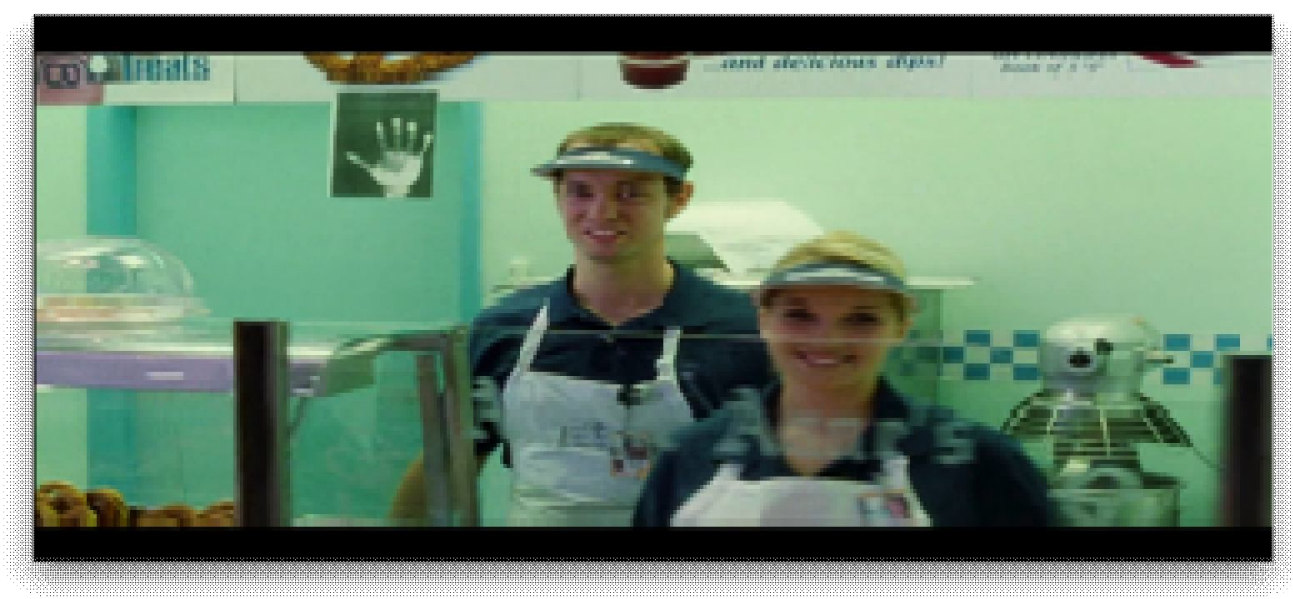

Fig. 11: Airport stores establishing a bond through Navroski's handprint

In his study on the space for agency in supermodernity, Richard S. Barnett asserts,

Though the agentive capacities in non-place are no doubt constrained, our conceptions of agency within such spaces would benefit by seeing potentiality-the capacity to produce 
relations within social (and spatial) systems-as recursively (re)produced. In this sense, the traveler constituted as a transhistorical consumer within the conditions of supermodernity may be seen both as inhabiting - and as limited to-a constrained agent function but also as participating in the production and reproduction of spatial practices composing terminal non-place. (Barnett 6o)

Victor Navroski creates an identity in a non-place, which has a relational value with the very space of the airport, where the individual does not exist in solitude, but also forms memories and symbols outside of the signage/codes of the airport. He reconstructs quite literally the architectural space of the airport when he creates his bedroom at Gate 67, a restaurant at the balcony looking out at the runway and also when he creates a gift for Amelia Warren (Catherine Zeta Jones), a flight attendant who he has fallen in love with. By the second half of the movie, one can see Victor well versed in the directions inside the airport, as he roams around in the comfort of his bathrobe and addresses everyone who works there, by their names. Furthermore he has acquired a way to earn even more money than Dixon by working as a construction worker at the airport.

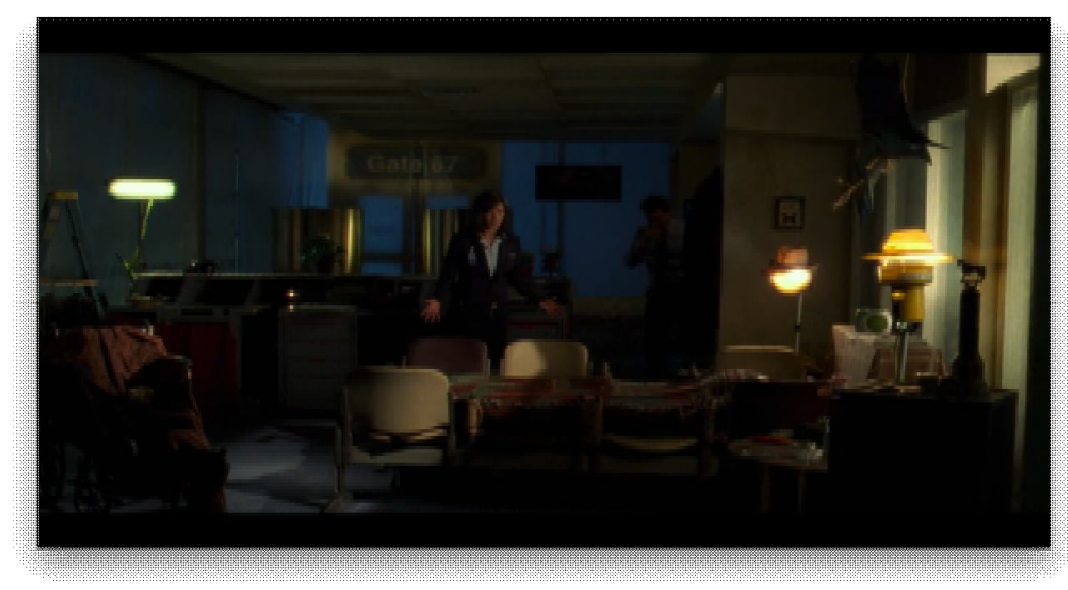

Fig. 12: Navroski turns Gate 67 into a bedroom for himself

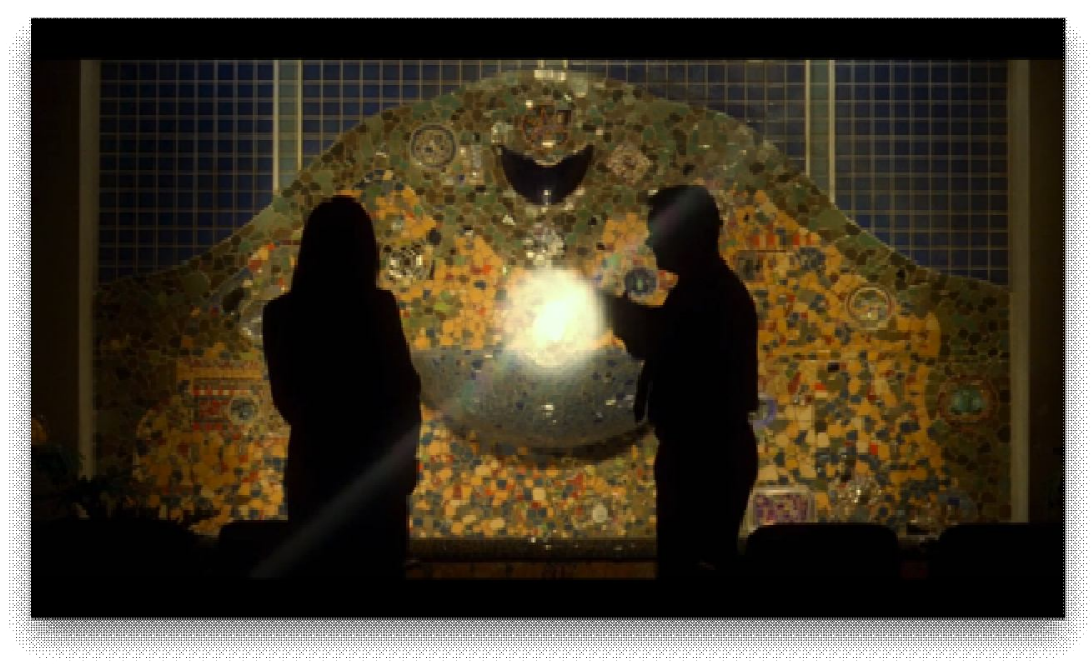

Fig. 13: Restructures a urinal to make a gift for Amelia 
The narrative also shows an interesting relationship between Victor Navroski and Amelia Warren. During their chance encounter at the airport terminal, Victor tries to communicate with Amelia as she seems annoyed and depressed, after he fails at it, and despite her angry resistance, he doesn't withdraw. From the first encounter to their last one, there is constant reference to history, they communicate with each other to express their feelings by referring to episodes from history.

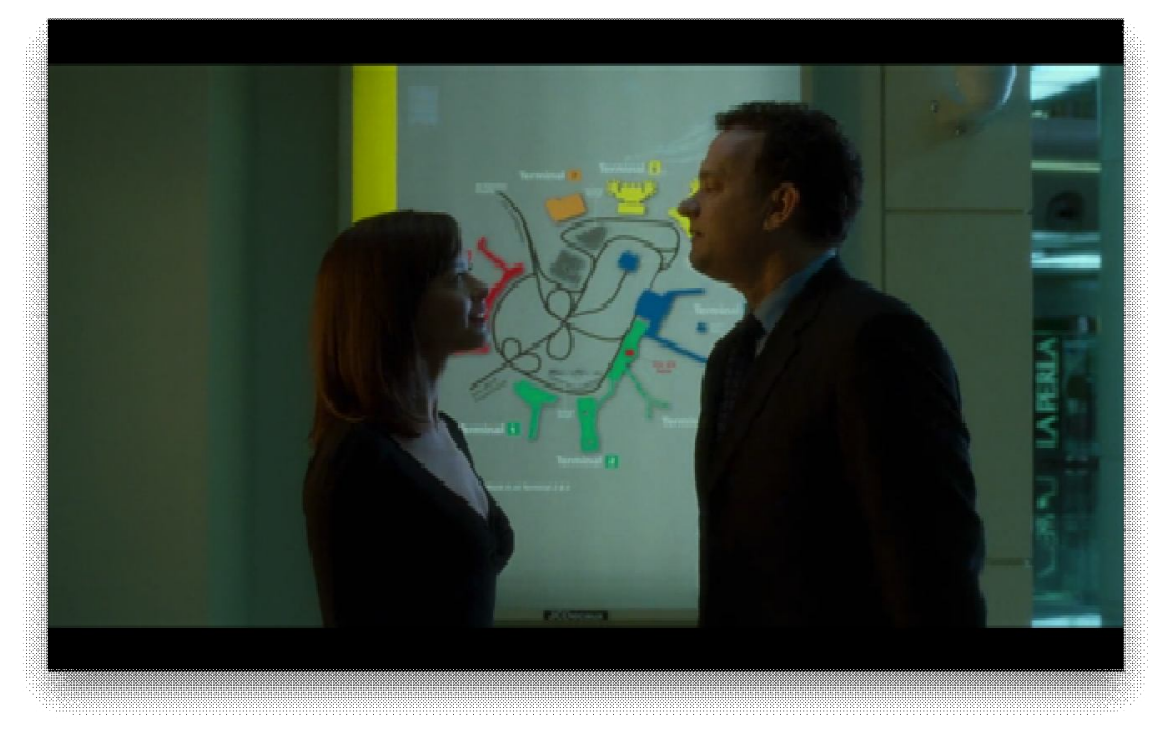

Fig. 14: The two characters are always against a backdrop of maps or cameras

Amelia: It's okay Victor, nobody really cares...(about history)...

Victor: No, I care. History is truth.

Amelia: ...I have been waiting for a phone call, Victor, for seven years. I know it's coming, that's why live out of hotels and a suitcase ready to go...I have waited my whole life, just don't know what the hell for.

Victor: I live here. I live here, Terminal Gate 67.

Amelia: You mean, at the airport?

Victor: It's home, like you. They tell me to wait (gesturing to his pager) so I wait...No, no I don't wait for flights, for meeting, I wait for...

Apart from their interactions on history, waiting is also the common force that is directing both their lives. Victor in this dialogue refers to airport as home both for him and for her. The space of the non-place has completely transformed for Victor, he is no more the solitary individual devoid of any identity in a trans-historical space, but he has habituated the non-place and has given it the relativity and cultural memory that one attaches with home. The promise for which Victor has travelled is also based on an archival photograph of "A Great Day in Harlem", which was printed in a Hungarian newspaper of 1958 , and had the pictures of 57 jazz artists. His father wanted to collect the autographs of all the listed musicians. He wrote to them with the help of nuns and waited all his life to collect these, but died before he could get the last one, that of Benny Golson, 
who played in New York's Ramada Inn, the only address which Victor repeated in the initial sequence of the film.

The day when the military coup ended in Karkhozia is also the day when he received a 24 emergency travel visa from Amelia, who arranged it with the help of a diplomatic friend. Spielberg places this day cleverly around Christmas, giving the movie a romanticized justice to Victor's attempt at fulfilling his father's last promise. Despite Dixon's attempt at restricting his passage into New York, he is again outdone by Victor, as even the chief officer joins in his collective and makes it possible for him to cross the threshold and fulfill his promise. The final scene ends with Victor declaring to the taxi driver "I am going home" and finally constructing a sentence in English, which is not flawed.

By analyzing the space of the airport through Spielberg's movie against the backdrop of Auge's anthropological theory of non-place, one can understand the discourse on airport outside of architectural, or geographical avenues to more cultural and sociological ones. The interaction of this liminal space with the traveller becomes informative when one understands the act of waiting as much as part of the journey for the traveller as the destination itself. The character of Victor Navroski formulates a temporal framework that is constructed through delay/waiting, the constant deferral to his journey, made him communicate with the space of the airport in ways that are hardly explored by a traveller. Even though there was a constant reiteration of space of airport based on a consumerist culture and supermodernity backdrop, the space also enabled other networks through which it momentarily suspended and processed a transaction which is based on construction of a new identity and a cultural collective, thus creating a new realization of the space of the airport. As Barnett discusses the ubiquity of surveillance and manipulation, veiled through the language of the space, he writes,

If, however, we regard agents as "cultural dopes or mere 'bearers of a mode production', with no worthwhile understanding of their surroundings or the circumstances of their action", then we risk conflating the importance of agency to an ideological puppet show in which lifeless marionettes perform in direct accordance with the strings and intentions of an unseen but nonetheless instrumental manipulator overseeing and producing a simulated reality. (Barnett 6o)

The agency that a traveller acquires in the movie, which usually gets absolved in the networking of surveillance and signage in real life, is something that should not be read as an exception (or fictional) in the workings of this non-place. Instead through this, one can tap into the unexplored domains of these transit-waiting zones, which might seem ephemeral but entail essential elements for a journey.

\footnotetext{
Notes

${ }^{\mathrm{i}}$ There is a slight confusion over the translated term supermodernity, while some scholars stick to John Howe's translation of supermodernity, to quote Bosteels(2003) for reference, "Augé's original term, surmodernité, at least indirectly seems to evoke some of what Georges Bataille had to say in 1968 about the prefix sur- in the context of surrealism as much as in the case of Nietzsche's philosophy of the Übermensch, in French surhomme, or "overman"', there are others who go with one of Auge's 2000 speech where he made a case for over-modernity rather than supermodernity, "I think in English one says "over-
} 
determination", in the language of Freud or Lacan - and what I want to say echoing these constructions is "over-modernity"'. To avoid confusion I would be using supermodernity for the length of this paper, as I followed Howe's translation of Marc Augé.

ii Libera, Chiara D. 'From Non-Place To Place:A Study Of European Public Space As A Space Of Identity'. Unpublished master diss., Master Erasmus Mundus Crossways in European Humanities, 2010. ?]

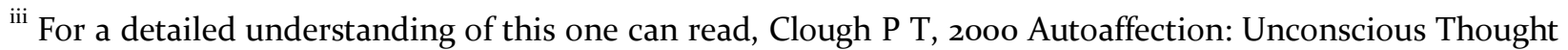
in the Age of Technology (University of Minnesota Press, Minneapolis, MN)] ?and Pascoe D, 2001 Airspaces (Reaktion, London)?

\section{References}

Augé, M. (1992). Non Places: Introduction to the Anthropology of Supermodernity. (J. Howe, Trans.) London: Verso.

Adey, P. (2003). Surveillance at the airport: surveilling mobility/mobilising surveillance . Environment and Planning , 1365-1380.

Berczeller, P. (2004, September 6). The man who lost his past. Retrieved March 29, 2015, from The Guardian: http://www.theguardian.com/film/2004/sep/o6/features.features11

Buchanan, I., \& Lambert, G. (2005). Introduction. In I. Buchanan, \& G. Lambert, Deleuze and Space (pp. 115). Edinburgh: Edinburgh University Press.

Fuller, G. (2002). The Arrow-Directional Semiotics: Wayfinding in Transit . Social Semiotics , 12 (3), 231244 .

Matienzo, M. (2004, January 15). The ethnology of nowhere, everywhere: Marc Augés Non-places as an analytical tool for supermodern ahistory and transience. Retrieved April 10, 2015, from http://matienzo.org/publications/:http://matienzo.org/storage/2004/2004-EthnologyOfNowhere.pdf

Osborne, P. (2001). Non-Places and the Spaces of Art. The Journal of Architecture , 183-194.

Speilberg, S. (Director). (2004). The Terminal [Motion Picture].

Üngür, E. (2012, July 7). Contradiction and Ambiguity in Non-Place: Non-Place as a Transitional Spatial Concept . Retrieved April 15, 2015, from Inter-Disciplinary.Net:A Global Network for Dynamic Research and Publishing: https://www.inter-disciplinary.net/critical-issues/wpcontent/uploads/2012/o7/ungursppaper.pdf

Kanika Sharma is currently teaching in the English Department of Shyama Prasad Mukherji College, University of Delhi. She completed her M.Phil. dissertation titled 'Sites of Cultural Poltics: Studying Memorials as Postmodern Space’ from Jamia Millia Islamia. Her research interests are memory studies, collective memory, film studies, visual arts and works of J.M Coetzee and Virginia Woolf. 